\title{
ПОРУШЕННЯ БІОХІМІЧНОГО СКЛАДУ ЖОВЧІ ЗА УМОВ ПОЄДНАНОЇ ТРАВМИ ЖИВОТА І ГРУДНОЇ КЛІТКИ В ПЕРІОД РАННІХ ПРОЯВІВ ТРАВМАТИЧНОЇ ХВОРОБИ ТА ЙОГО КОРЕКЦІЯ ТІОТРИАЗОЛІНОМ
}

Вступ. Травми продовжують залишатися найпоширенішою причиною смертності в цілому світі. У структурі бойової травми тупі й проникні ушкодження грудної клітки і живота займають третє місце, поступаючись пораненням кінцівок та голови.

Мета дослідження - з'ясувати характер порушення жовчоутворювальної фуннкції печінки за умов поєднаної травми живота і грудної клітки щурів у ранній період травматичної хвороби та оцінити ефрективність його корекції тіотриазоліном.

Методи дослідження. Експерименти проведено на 86-ти нелінійних білих щурах-самцях масою 200-220 г, яких поділили на п'ять груп: контрольну та чотири дослідних. Травми наносили за умов тіопентал-натрієвого наркозу в дозі 40 мг/кг маси тварини. До контрольної групи ввійшли інтактні тварини, яких тільки вводили в наркоз. У 1-й дослідній групі щурам моделювали травму грудної клітки, у 2-й тупу травму живота, в 3-й - ці травми поєднували, в 4-й- тваринам з поєднаною травмою внутрішньочеревно вводили тіотриазолін у дозі 9,1 мг·кح'. Через 1, 3 і 7 діб після нанесення травм за умов тіопентал-натрієвого наркозу в щурів катетеризували загальну жовчну протоку та протягом 60 хв збирали жовч, в якій визначали концентрацію сумарних жовчних кислот і холестеролу, розраховували холато-холестероловий коефріцієнт.

Результати й обговорення. При нанесенні ізольованих травм грудної клітки, живота та їх поєднанні суттєво порушувалась жовчоутворювальна функція печінки, що проявлялось зниженням синтезу холатів і зростанням холато-холестеролового коефріцієнта. За тяжкістю розвитку печінкової диссрункції їх можна розподілити так: ізольована травма грудної клітки гізольована травма живота поєднана травма. Унаслідок виявлених порушень істотно підвищувався холато-холестероловий коефріцієнт, який домінував за умов ізольованої травми живота та поєднаної травми. Зміщення балансу в бік накопичення холестеролу посилювало літогенні властивості жовчі. Семиденне застосування тіотриазоліну в групі тварин з поєднаною травмою сприяло істотному збільшенню вмісту в жовчі сумарних жовчних кислот, зростанню холато-холестеролового коефріцієнта, не впливало на концентрацію холестеролу в жовчі.

Висновки. Поєднана травма живота і грудної клітки сприяє більшому зниженню фрункціональної спроможності печінки порівняно з ізольованими ураженнями. В його основі лежить пригнічення синтетичних процесів у мікросомальній системі гепатоцитів. Тіотриазолін здатен знизити негативний вплив патогенних чинників травми на фрункціональну спроможність гепатоцитів, що слід враховувати в комплексній інтенсивній терапії поєднаної травми живота і грудної клітки.

КЛЮЧОВІ СЛОВА: поєднана травма; грудна клітка; живіт; жовчоутворення; тіотриазолін.

ВСТУП. Травми продовжують залишатися найпоширенішою причиною смертності в цілому світі й посідають третє місце, поступаючись лише серцево-судинним захворюванням та онкологічній патології. За даними ВООЗ, від травм щорічно гинуть до 2 млн осіб і понад 45 млн осіб стають інвалідами $[1,2]$.

Зростання травматизму в сучасному урбанізованому суспільстві зумовлене значним збільшенням числа надзвичайних ситуацій техногенного, природного, соціально-політичного i (c) О. А. Зачепа, А. А. Гудима, Ю. І. Сушко, Т. Я. Ярошенко, 2019. воєнного характеру. В їх структурі домінують множинні й поєднані ушкодження, які характеризуються значною тяжкістю і високою летальністю, що пов'язано із синдромом взаємного обтяження та розвитком поліорганної диссрункції і недостатності [3, 4].

У структурі бойової травми, незважаючи на зміну характеру ведення війни і, водночас, удосконалення засобів захисту тіла, тупі й проникні ушкодження грудної клітки і живота займають третє місце, поступаючись пораненням кінцівок та голови, й нерідко супроводжуються розвитком поліорганної диссрункції і недостатності [5]. 
Тому поглиблення дослідження механізмів формування поліорганної недостатності за умов поєднаної травми живота і грудної клітки є актуальним завданням сучасної медицини. При цьому недостатньо вивчено гепатопротекторну активність тіотриазоліну, який позитивно себе зарекомендував за умов скелетної травми [6].

Мета дослідження - з'ясувати характер порушення жовчоутворювальної функції печінки за умов поєднаної травми живота і грудної клітки щурів у ранній період травматичної хвороби та оцінити ефективність його корекції тіотриазоліHOM.

МЕТОДИ ДОСЛІДЖЕННЯ. Експерименти проведено на 86-ти нелінійних білих щурах-самцях масою 200-220 г, яких поділили на п'ять груп: контрольну та чотири дослідних. Травми наносили за умов тіопентал-натрієвого наркозу в дозі 40 мг/кг маси тварини. До контрольної групи ввійшли інтактні тварини, яких тільки вводили в наркоз. У 1-й дослідній групі щурам моделювали травму грудної клітки. В асептичних умовах по передній поверхні лівої половини грудної клітки пересікали 3 суміжних ребра 3 досягненням відкритого пневмотораксу, який ушивали. У 2-й дослідній групі моделювали тупу травму живота шляхом нанесення однократного дозованого удару по черевній порожнині ударним пристроєм діаметром 2,5 см² з енергією 0,70 Дж. У 3-й дослідній групі ці травми поєднували. У 4-й дослідній групі застосовували тіотриазолін виробництва компанії "Артеріум" (Україна), який вводили внутрішньочеревно з першого дня після нанесення поєднаної травми впродовж 6-ти діб однократно в дозі 9,1 мг/кг, що відповідало 100 мг препарату для дорослої людини [7]. Для забезпечення адекватності експерименту тваринам інших дослідних груп вводили еквівалентний об'єм фрізіологічного розчину.

Тварин виводили 3 експерименту через 1, 3 і 7 діб після нанесення травм. За умов тіопентал-натрієвого наркозу в щурів катетеризували загальну жовчну протоку і протягом 60 хв збирали жовч, після чого їх забивали методом тотального кровопускання із серця. Для дослідження брали жовч, в якій, відповідно до рекомендацій [8], визначали концентрацію сумарних жовчних кислот і холестеролу. На основі отриманих результатів розраховували холато-холестероловий коефіцієнт (сумарні жовчні кислоти/холестерол), який вказує на літогенні властивості жовчі.

Усі експерименти виконували згідно із загальними правилами і положеннями Європейської конвенції про захист хребетних тварин, що використовуються для дослідних та інших наукових цілей (Страсбург, 1986), Загальними етичними принципами експериментів на тваринах (Київ, 2001), Законом України "Про захист тварин від жорстокого поводження”, (2006, додаток 4), а також відповідно до Науково-практичних рекомендацій з утримання лабораторних тварин та роботи з ними.

Вірогідність відмінностей між дослідними групами оцінювали з використанням непараметричного критерію Манна - Уїтні.

РЕЗУЛЬТАТИ Й ОБГОВОРЕННЯ. ЯК ВИДНО з таблиці 1, модельовані травми, порівняно 3 контролем, супроводжувалися зниженням вмісту в жовчі сумарних жовчних кислот. За умов проникного поранення грудної клітки він до

Таблиця 1 - Вміст сумарних жовчних кислот у жовчі $\left(г \cdot \pi^{-1}\right)$ після нанесення травми грудної клітки, тупої травми живота і їх поєднання (Me (LQ; UQ) - медіана (нижній та верхній квартилі))

\begin{tabular}{|c|c|c|c|c|}
\hline \multirow{2}{*}{ Вид травми } & \multirow{2}{*}{ Контроль } & \multicolumn{3}{|c|}{ Тривалість посттравматичного періоду } \\
\hline & & 1 доба & 3 доби & 7 діб \\
\hline $\begin{array}{l}\text { Травма грудної клітки } \\
\text { (1-ша група) }\end{array}$ & \multirow[t]{3}{*}{$\begin{array}{c}1,76 \\
(1,67 ; 1,91) \\
(n=6)\end{array}$} & $\begin{array}{c}1,50 \\
(1,35 ; 1,69) \\
(n=7)\end{array}$ & $\begin{array}{c}1,35^{*} \\
(1,24 ; 1,41) \\
(n=6)\end{array}$ & $\begin{array}{c}1,65^{3} \\
1,58 ; 1,80 \\
(n=7)\end{array}$ \\
\hline $\begin{array}{l}\text { Тупа травма живота } \\
\text { (2-га група) }\end{array}$ & & $\begin{array}{c}1,35^{\star} \\
(1,20 ; 1,39) \\
(n=7)\end{array}$ & $\begin{array}{c}1,13^{\star} \\
(0,94 ; 1,20) \\
(n=6)\end{array}$ & $\begin{array}{c}1,13^{\star} \\
(1,05 ; 1,20) \\
(n=6)\end{array}$ \\
\hline $\begin{array}{l}\text { Поєднана травма } \\
\text { (3-тя група) }\end{array}$ & & $\begin{array}{c}1,05^{\star} \\
(0,99 ; 1,16) \\
(n=6)\end{array}$ & $\begin{array}{c}0,90^{\star} \\
(0,84 ; 0,96) \\
(n=6)\end{array}$ & $\begin{array}{c}0,75^{\star 1,3} \\
(0,68 ; 0,75) \\
(n=5)\end{array}$ \\
\hline \multicolumn{2}{|l|}{$\mathrm{p}_{1-2}$} & $>0,05$ & $<0,05$ & $<0,05$ \\
\hline \multicolumn{2}{|l|}{$p_{1-3}$} & $<0,05$ & $<0,05$ & $<0,05$ \\
\hline \multicolumn{2}{|l|}{$p_{2-3}$} & $<0,05$ & $>0,05$ & $<0,05$ \\
\hline
\end{tabular}

Примітки. Тут і в таблицях 2, 3:

1. * - відмінності стосовно контрольної групи статистично вірогідні $(p<0,05)$.

2. $p_{1-2}$ - вірогідність відмінностей між 1-ю і 2-ю дослідними групами.

3. $\mathrm{p}_{1-3}$ - вірогідність відмінностей між 1-ю і 3-ю дослідними групами.

4. $\mathrm{p}_{2-3}$ - вірогідність відмінностей між 2-ю і 3-ю дослідними групами. 
3-ї доби посттравматичного періоду досягав мінімальної величини і ставав меншим, ніж у контрольній групі (на 23,3 \% р<0,05). До 7-ї доби показник зростав, статистично вірогідно не відрізнявся від такого в контрольній групі $(p>0,05)$ і був вищим, ніж у попередній термін спостереження (на 22,2 \%, p<0,05). За умов тупої травми живота спостерігали більш виражені порушення. Уже через 1 добу після нанесення травми, порівняно з контрольною групою, вміст у жовчі сумарних жовчних кислот статистично вірогідно зменшувався (на 23,3 \%, p<0,05). У подальшому (до 3-ї доби) показник знижувався ще більше (на $35,8 \%, p<0,05)$ і залишався на такому ж рівні до 7-ї доби.

Найбільші порушення вмісту в жовчі сумарних жовчних кислот відмічали після нанесення поєднаної травми грудної клітки та живота. Через 1 добу посттравматичного періоду показник знижувався порівняно з контрольною групою (на 40,3\%, p<0,05). У подальшому (через 3 доби) він ще більше зменшувався (на 48,9\%, р<0,05), досягаючи мінімальної величини через 7 діб (на $57,4 \%, p<0,05)$. У цей термін вміст у жовчі сумарних жовчних кислот ставав статистично вірогідно нижчим порівняно з попередніми термінами спостереження (відповідно, на 28,6 і $16,7 \%, p<0,05)$.

Порівнюючи дослідні групи між собою, з'ясували, що за умов поєднаної травми вміст у жовчі сумарних жовчних кислот через 1 добу був істотно меншим, ніж після нанесення ізольованих травм грудної клітки та живота (відповідно, на $\left.30,0 \%, \mathrm{p}_{1-3}<0,05,22,2 \%, \mathrm{p}_{2-3}<0,05\right)$. Через 3 доби показник на тлі ізольованої травми живота виявився суттєво нижчим, ніж після моделювання проникної травми грудної клітки (на 16,3 \%, $\left.\mathrm{p}_{1-2}<0,05\right)$. Після нанесення поєднаної травми в цей термін спостереження він був найменшим (відповідно, на 33,3 \% порівняно з 1-ю дослідною групою $\left(p_{1-3}<0,05\right)$ та на 20,3 \% порівняно 3 2-ю дослідною групою), проте результат виявився статистично не значущим $\left(\mathrm{p}_{2-3}<0,05\right)$. Через 7 діб посттравматичного періоду після моделювання ізольованої травми живота вміст у жовчі сумарних жовчних кислот був нижчим порівняно 3 1-ю дослідною групою (на 31,5 \%, $\mathrm{p}_{1-2}<0,05$ ). Після нанесення поєднаної травми показник ставав статистично вірогідно меншим порівняно з іншими дослідними групами (відповідно, на 54,5 \%, $\left.\mathrm{p}_{1-3}<0,05,33,6 \%, \mathrm{p}_{2-3}<0,05\right)$.

Аналізуючи вміст холестеролу в жовчі (табл. 2), встановили, що через 1 добу посттравматичного періоду його величина зростала лише у групі тварин 3 ізольованою травмою живота (на 27,3 \%, p<0,05), тоді як відмінності між дослідними групами в цей термін спостереження виявилися статистично не вірогідними ( $\mathrm{p}_{1-2}>0,05$, $\left.p_{1-3}>0,05, p_{2-3}>0,05\right)$. Через 3 доби він продовжував залишатися істотно більшим, порівняно 3 контрольною групою, лише на тлі ізольованої травми живота (на 31,9 \%, р<0,05). Водночас за умов поєднаної травми показник у цей термін спостереження знижувався і виявився суттєво меншим, ніж у попередній термін спостереження (на 13,0 \%, p<0,05) та порівняно 3 іншими дослідними групами (відповідно, на 20,0 \%, $\left.\mathrm{p}_{1-3}<0,05,31,0 \%, \mathrm{p}_{2-3}<0,05\right)$. Через 7 діб посттравматичного періоду вміст холестеролу в жовчі в дослідних групах істотно не відрізнявся від такого в контрольній групі $(p<0,05)$. У 3-й дослідній групі показник продовжував залишатися істотно меншим порівняно 3 1-ю добою спостереження (на 17,4 \%, p<0,05). Під час порівнювання в цей термін спостереження дослідних груп між собою було встановлено, що за умов ізольованої травми живота вміст у жовчі холестеролу виявився істотно більшим порівняно 3 1-ю (на 30,0 \%, p $1-2_{<}<0,05$ ) і 3-ю (на 36,8 \%, $\left.\mathrm{p}_{2-3}<0,05\right)$ дослідними групами.

Динаміку величини холато-холестеролового коефріцієнта наведено в таблиці 3. За умов ізо-

Таблиця 2 - Вміст холестеролу в жовчі $\left(\Gamma^{\cdot} \boldsymbol{л}^{-1}\right)$ після нанесення закритої травми живота, травми грудної клітки та їх поєднання (Me (LQ; UQ) - медіана (нижній та верхній квартилі))

\begin{tabular}{|c|c|c|c|c|}
\hline \multirow{2}{*}{ Вид травми } & \multirow{2}{*}{ Контроль } & \multicolumn{3}{|c|}{ Тривалість посттравматичного періоду } \\
\hline & & 1 доба & 3 доби & 7 діб \\
\hline $\begin{array}{l}\text { Травма грудної клітки } \\
\text { (1-ша група) }\end{array}$ & \multirow[t]{3}{*}{$\begin{array}{c}0,22 \\
(0,22 ; 0,23) \\
(n=6)\end{array}$} & $\begin{array}{c}0,26 \\
(0,21 ; 0,26) \\
(n=7)\end{array}$ & $\begin{array}{c}0,25 \\
(0,21 ; 0,28) \\
(n=6)\end{array}$ & $\begin{array}{c}0,20 \\
(0,19 ; 0,22) \\
(n=7)\end{array}$ \\
\hline $\begin{array}{l}\text { Тупа травма живота } \\
\text { (2-га група) }\end{array}$ & & $\begin{array}{c}0,28^{*} \\
(0,24 ; 0,30) \\
(n=7)\end{array}$ & $\begin{array}{c}0,29 * \\
(0,28 ; 0,29) \\
(n=6)\end{array}$ & $\begin{array}{c}0,26 \\
(0,25 ; 0,28) \\
(n=6)\end{array}$ \\
\hline $\begin{array}{l}\text { Поєднана травма } \\
\text { (3-тя група) }\end{array}$ & & $\begin{array}{c}0,23 \\
(0,22 ; 0,26) \\
(n=6)\end{array}$ & $\begin{array}{c}0,20^{1} \\
(0,20 ; 0,21) \\
(n=6)\end{array}$ & $\begin{array}{c}0,19^{1} \\
(0,18 ; 0,20) \\
(n=5)\end{array}$ \\
\hline \multicolumn{2}{|l|}{$p_{1-2}$} & $>0,05$ & $>0,05$ & $<0,05$ \\
\hline \multicolumn{2}{|l|}{$p_{1-3}$} & $>0,05$ & $<0,05$ & $>0,05$ \\
\hline \multicolumn{2}{|l|}{$p_{2-3}$} & $>0,05$ & $<0,05$ & $<0,05$ \\
\hline
\end{tabular}


Таблиця 3 - Величина холато-холестеролового коефіцієнта (ум. од.) після нанесення травми грудної клітки, закритої травми живота і їх поєднання (Me (LQ; UQ) - медіана (нижній та верхній квартилі))

\begin{tabular}{|c|c|c|c|c|}
\hline \multirow{2}{*}{ Вид травми } & \multirow{2}{*}{ Контроль } & \multicolumn{3}{|c|}{ Тривалість посттравматичного періоду } \\
\hline & & 1 доба & З доби & 7 діб \\
\hline $\begin{array}{l}\text { Травма грудної клітки } \\
\text { (1-ша група) }\end{array}$ & \multirow[t]{3}{*}{$\begin{array}{c}8,03 \\
(7,22 ; 9,06) \\
(n=6)\end{array}$} & $\begin{array}{c}7,11 \\
(5,18 ; 7,38) \\
(n=7)\end{array}$ & $\begin{array}{c}5,09^{\star} \\
(4,99 ; 6,22) \\
(n=6)\end{array}$ & $\begin{array}{c}8,57^{3} \\
(7,11 ; 9,15) \\
(n=7)\end{array}$ \\
\hline $\begin{array}{l}\text { Тупа травма живота } \\
\text { (2-га група) }\end{array}$ & & $\begin{array}{c}5,01^{*} \\
(4,20 ; 5,40) \\
(n=7)\end{array}$ & $\begin{array}{c}3,93^{\star} \\
(3,33 ; 4,37) \\
(n=6)\end{array}$ & $\begin{array}{c}4,35^{\star} \\
(3,43 ; 4,85) \\
(n=6)\end{array}$ \\
\hline $\begin{array}{l}\text { Поєднана травма } \\
\text { (3-тя група) }\end{array}$ & & $\begin{array}{c}4,61^{\star} \\
(4,29 ; 4,89) \\
(n=6)\end{array}$ & $\begin{array}{c}4,25^{\star} \\
(4,02 ; 4,82) \\
(n=6)\end{array}$ & $\begin{array}{c}4,13^{\star} \\
(3,17 ; 4,87) \\
(n=5)\end{array}$ \\
\hline \multicolumn{2}{|l|}{$\mathrm{p}_{1-2}$} & $>0,05$ & $<0,05$ & $<0,05$ \\
\hline \multicolumn{2}{|l|}{$p_{1-3}$} & $<0,05$ & $>0,05$ & $<0,05$ \\
\hline \multicolumn{2}{|l|}{$p_{2-3}$} & $>0,05$ & $>0,05$ & $>0,05$ \\
\hline
\end{tabular}

льованої травми грудної клітки показник до 3-ї доби ставав суттєво меншим порівняно 3 контрольною групою (на 36,6 \%, р<0,05). До 7-ї доби він суттєво збільшувався порівняно з попереднім терміном спостереження (на 68,4 \%, p<0,05) i досягнув рівня контрольної групи ( $>0,05)$.

Після моделювання ізольованої травми живота показник уже з 1-ї доби посттравматичного періоду ставав істотно меншим, ніж у контрольній групі (на 37,6 \%, р<0,05), і залишався на такому ж рівні до 7-ї доби. За умов поєднаної травми закономірність була аналогічною: через 1 добу показник знижувався (на 42,6 \%, p<0,05) і залишався на такому ж рівні до 7-ї доби.

Порівнюючи дослідні групи між собою, встановили, що через 1 добу зі збільшенням тяжкості травми холато-холестероловий індекс знижувався. Відмінності виявилися статистично значущими між групами тварин з ізольованою травмою живота та поєднаною травмою, при якій показник був на 34,7 \% меншим ( $\left.p_{1-3}<0,05\right)$. Через 3 доби холато-холестероловий коефіцієнт виявився статистично вірогідно меншим за умов ізольованої травми живота порівняно 3 ізольованою травмою грудної клітки (відповідно, на 22,8 \%, $\left.\mathrm{p}_{1-2}<0,05\right)$. Через 7 діб ізольована травма живота і поєднана травма зумовлювали суттєво менший холато-холестероловий коефіцієнт порівняно 3 ізольованою травмою грудної клітки (відповідно, на $\left.49,2 \%, p_{1-2}<0,05,51,8 \%, p_{1-3}<0,05\right)$.

Таким чином, за умов нанесення ізольованих травм грудної клітки, живота і їх поєднання суттєво порушується жовчоутворювальна фрункція печінки, що насамперед проявляється зниженням синтезу холатів та зростанням холато-холестеролового коефіцієнта. Враховуючи той факт, що жовчоутворення належить до органоспецифрічних фрункцій печінки, є чутливим індикатором ії̈ диссрункції [9], можна стверджувати, що модельовані травми супроводжуються істотним впливом на фрункціональний стан печінки [10]. За тяжкістю розвитку печінкової диссрункції їх можна розподілити так: ізольована травма грудної клітки $\leftarrow$ ізольована травма живота $\leftarrow$ поєднана травма. За умов ізольованої травми грудної клітки вміст сумарних жовчних кислот, порівняно 3 контрольною групою, досягає мінімального рівня до 3-ї доби і нормалізується до 7-ї доби. Після нанесення ізольованої травми живота показник істотно зменшується вже через 1 добу та залишається на такому ж рівні до 7-ї доби. Після моделювання поєднаної травми він поступово знижується до 7-ї доби. Через 1 і 7 діб за умов поєднаної травми вміст сумарних жовчних кислот суттєво менший, ніж в інших дослідних групах. Отже, додаткове проникне поранення грудної клітки істотно поглиблює тяжкість тупої травми живота. Можна припустити, що епізод гіпоксії, пов'язаний з раптовим виключенням лівої легені з акту дихання і газообміну, суттєво порушує антиоксидантно-прооксидантний баланс печінки в бік переважання прооксидантних механізмів, що підтвердили наші попередні дослідження [11]. Високу чутливість жовчоутворювальної функції печінки до гіпоксії показали й інші автори [12]. Відомо, що пул жовчних кислот, що виділяються із жовчю, складається 3 тих, які повертаються до печінки внаслідок кишково-печінкової рециркуляції, і тих, які синтезуються 3 холестеролу в мікросомальній системі гепатоцитів [13]. Можна припустити, що провідним механізмом зниження вмісту жовчних кислот $€$ порушення здатності печінки захоплювати жовчні кислоти з крові та синтезувати їх з холестеролу. Обидва процеси є мембранозалежними і підтверджують розвиток печінкової диссрункції [10]. Це припущення підтверджується збільшенням вмісту холестеролу в жовчі після моделювання тупої травми живота через 1 і 3 доби після нанесення травми - фрактично в гострий 
період, пов'язаний із травматичним шоком. Звертає на себе увагу той фракт, що за умов поєднаної травми вміст холестеролу в жовчі через 3 і 7 діб стає нижчим, ніж через 1 добу, що на тлі зменшення вмісту холатів свідчить про глибше порушення синтетичної функції печінки, в тому числі й холестеролу, синтез якого в печінці на 80 \% задовольняє потреби організму.

Внаслідок виявлених порушень істотно зростає холато-холестероловий коефіцієнт, який домінує за умов ізольованої травми живота і поєднаної травми. Зміщення балансу в бік накопичення холестеролу посилює літогенні властивості жовчі. Отже, провідним механізмом посилення літогенності жовчі є тупа травма живота.

Як зазначалося, порушення жовчоутворювальної функції печінки пов'язане зі станом мембран ендоплазматичного ретикулума гепатоцитів, які уражаються одними з перших за умов гіпоксії і накопичення в гепатоцитах активних фрорм кисню та вільних радикалів. Тому для корекції виявлених порушень було вибрано вітчизняний препарат “Тіотриазолін”, в якого доведеними $€$ антиоксидантний, протиішемічний, енерготропний, мембраностабілізувальний, протизапальний, репаративний і антиапоптичний еоректи [14].

Результати досліджень показали (рис. 1-3), що семиденне застосування тіотриазоліну в групі тварин з поєднаною травмою сприяло істотному збільшенню вмісту в жовчі сумарних жовчних кислот (на 60,0 \%, р<0,05), зростанню холато-холестеролового коефріцієнта (на 31,2 \%, $p<0,05)$, не впливало на концентрацію холестеролу в жовчі ( $p>0,05)$. До 7-ї доби показники не досягали рівня контрольної групи, проте можна стверджувати, що препарат мав виражений

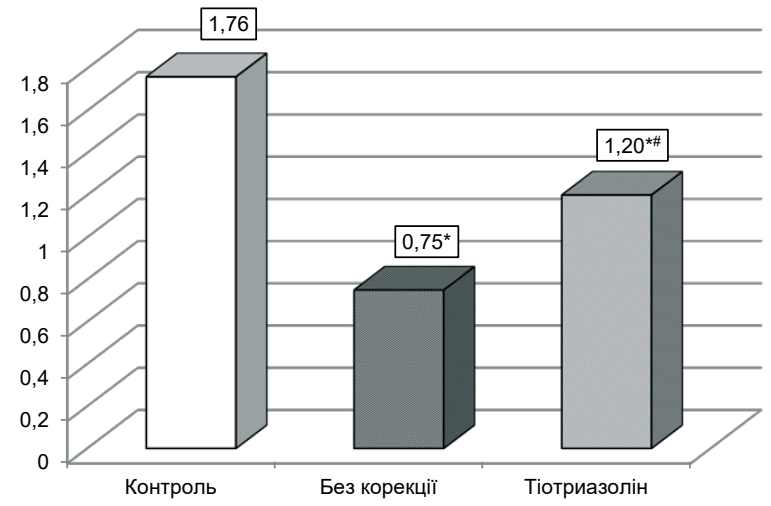

Рис. 1. Вплив тіотриазоліну на вміст сумарних жовчних кислот у жовчі $\left(\left\ulcorner\cdot л^{-1}\right)\right.$ після моделювання поєднаної травми живота і грудної клітки.

Примітка. Тут і на рисунках 2, 3:

1. * - відмінності стосовно контрольної групи статистично вірогідні $(p<0,05)$.

2. \# - відмінності стосовно травмованих тварин без корекції статистично вірогідні $(p<0,05)$.

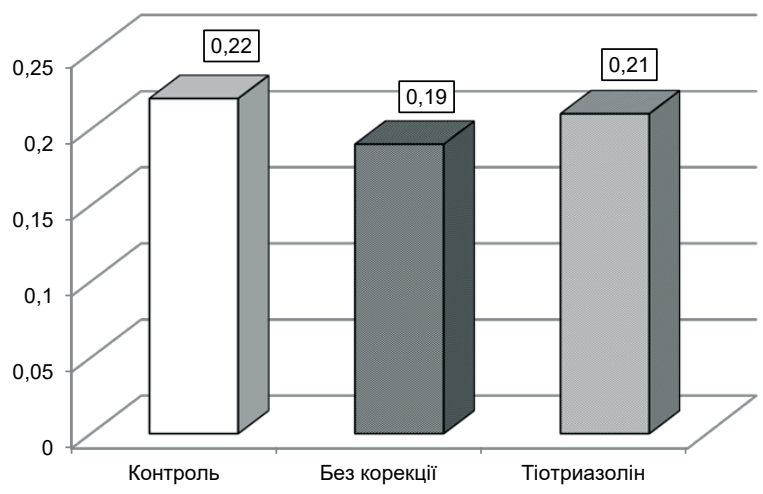

Рис. 2. Вплив тіотриазоліну на вміст холестеролу в жовчі $\left(\left\ulcorner\cdot л^{-1}\right)\right.$ після моделювання поєднаної травми живота і грудної клітки.

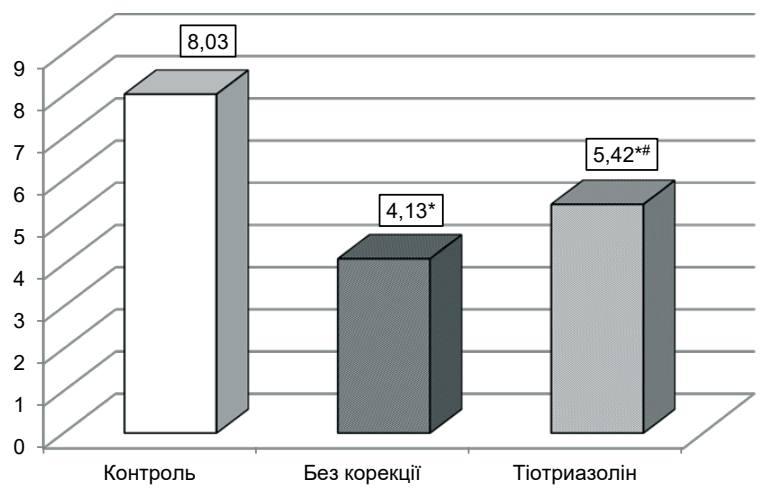

Рис. 3. Вплив тіотриазоліну на холато-холестероловий коефіцієнт (ум. од.) після моделювання поєднаної травми живота і грудної клітки.

позитивний вплив на стан мікросомальної системи гепатоцитів, де відбувався синтез жовчних кислот з холестеролу. Важливо відмітити, що за даних умов препарат знижував літогенні властивості жовчі. Оскільки на тлі тяжкої травми черевної порожнини ентеральне харчування, яке б сприяло природному відтоку жовчі, відтерміновується, завдяки застосуванню тіотриазоліну можна зменшити виділення холестеролу з жовчю і поліпшити стабільність жовчної міцели.

Таким чином, поєднана травма живота i грудної клітки сприяє більшому зниженню функціональної спроможності печінки порівняно 3 ізольованими ураженнями [15]. В його основі лежить пригнічення синтетичних процесів у мікросомальній системі гепатоцитів. Тіотриазолін здатен знизити негативний вплив патогенних чинників травми на фрункціональну спроможність гепатоцитів, що слід враховувати в комплексній інтенсивній терапії поєднаної травми живота і грудної клітки.

ВИСНОВКИ. 1. За умов нанесення ізольованих травм грудної клітки, живота і їх поєднання, порівняно з тваринами контрольної групи, суттєво порушується жовчоутворювальна фрункція печінки, що проявляється зниженням синтезу 
холатів і зростанням холато-холестеролового коефіцієнта. Порушення наростають від травми грудної клітки до травми живота і поєднаної травми.

2. Застосування тіотриазоліну в дозі 9,1 мг·к $\Gamma^{-1}$ щоденно внутрішньочеревно у тварин з поєдна- ною травмою живота та грудної клітки через 7 діб супроводжується істотним зростанням, порівняно зі щурами без корекції, вмісту сумарних жовчних кислот, не впливає на концентрацію холестеролу і сприяє зниженню літогенних властивостей жовчі.

\section{СПИСОК ЛІТЕРАТУРИ}

1. Bouglé A. Resuscitative strategies in traumatic hemorrhagic shock / A. Bouglé, A. Harrois, J. Duranteau // Annals of Intensive Care. - 2013. - 3 (1). - P. 1

2. Management of the patients with blunt renal trauma: 20 years of clinical experience / L. P. Sarychev, Y. V. Sarychev, H. L. Pustovoyt [et al.] // Wiadomości Lekarskie. - 2018. - 71 (3 pt. 2). - P. 719-722.

3. Гур'єв С. О. Аналіз безпосередніх причин смерті у постраждалих із політравмою та пошкодженням скелета / С. О. Гур'єв, А. Ю. Філь, О.М. Танасієнко // Травма. - 2015. - 16, № 4. - С. 7-10.

4. Філь А. Ю. Хірургічна концепція лікування постраждалих із політравмою у гострому періоді / А. Ю. Філь // Травма. - 2014. - 15, № 5. - С. 20-23.

5. Гайда І. М. Особливості структури та перебігу сучасної бойової травми у військовослужбовців Збройних Сил України / І. М. Гайда, М.І.Бадюк Ю. І. Сушко // Патологія. - 2018. - 15, № 1. - С. 73-76.

6. Prydruha S. M. Pathogenetic features the late current manifestations in an experiment traumatic disease and its correction tiotryazolin / S. M. Prydruha // Journal of Health Sciences. - 2013. - № 3. - P. 111-120.

7. Гудима А. А. Вплив лансопразолу, метронідазолу і кларитроміцину на фрункціональний стан печінки і його корекція тіотриазоліном в умовах хронічного експериментального гепатиту / А. А. Гудима, В. В. Підгірний // Запоріз. мед. журн. - 2007. - № 5. - С. 33-37.

8. Доклінічні дослідження лікарських засобів : метод. рек. / за ред. О. В. Стефанова. - К. : Авіцена, 2001. - 528 c.

9. Гудима А. А. Динаміка показників жовчоутворювальної функції печінки у відповідь на скелетну, черепно-мозкову та поєднану травму в ранній період травматичної хвороби / А. А. Гудима, І. А. Михайлюк,
В. М. Михайлюк // Мед. і клініч. хімія. - 2015. - 17, № 3 (64). - С. 66-69.

10. Волотовська Н. В. Зміни активності глутатіонової системи внутрішніх органів у перші години експериментального ішемічно-реперфузійного синдрому кінцівки, поєднаного з крововтратою та механічною травмою / Н. В. Волотовська, Т. Кліфрф Нхоквара, І. В. Жулкевич // Здобутки клініч. і експерим. медицини. - 2019. - № 1. - С. 23-27.

11. Зачепа О. А. Порушення антиоксидантно-прооксидантного балансу в печінці за умов поєднаної абдомінальної і торакальної травми / О. А. Зачепа, Ю. І. Сушко // Екстрена медична допомога в надзвичайних умовах : матеріали Всеукр. наук.-практ. конфр., 22-24 лют. 2019 р. - Тернопіль : ТДМУ, 2019. - С. 45-46.

12. Волотовська Н. В. Роль гемічної гіпоксії в патогенезі порушень жовчоутворювальної і жовчовидільної фрункції печінки на тлі скелетної травми в ранньому посттравматичному періоді / Н. В. Волотовська, А. А. Гудима // Здобутки клініч. і експерим. медицини. - 2011. - № 2 (15). - С. 31-33.

13. Чекман И. С. Микросомальная фрерментная система оранизма / И. С. Чекман, Е. А. Посохова, Е. Г. Береговая. - К., 1996. - 80 с.

14. Место тиотриазолина в галерее современных метаболитотропных лекарственных средств / И. Ф. Беленичев, В. А. Визир, В. И. Мамчур, А. В. Курята // Запорож. мед. журн. - 2019. - 21, № 1. - С. 118-128.

15. Оцінка безпечності внутрішньопечінкового введення $10 \%$ розчину кальцію хлориду у щурів лінії wistar: експериментальне дослідження / О. І. Дронов, І. О. Ковальська, С. В. Земсков [та ін.] // Здобутки клініч. і експерим. медицини. - 2019. - № 2. - С. 125129.

\section{REFERENCES}

1. Bouglé, A., Harrois, A., \& Duranteau, J. (2013). Resuscitative strategies in traumatic hemorrhagic shock. Annals of Intensive Care, 3, 1, 1.

2. Sarychev, L.P., Sarychev, Y.V., Pustovoyt, H.L., Sukhomlin, S.A., \& Suprunenko, S.M. (2018). Management of the patients with blunt renal trauma: 20 years of clinical experience. Wiadomości Lekarskie, 71 (3 pt. 2), 719-722.

3. Huriev, S.O., Fil, A.Yu., \& Tanasiienko, O.M. (2015). Analiz bezposerednikh prychyn smerti u postrazhdalykh 
iz politravmoiu ta poshkodzhenniam skeleta [Analysis of immediate causes of death in victims with polytrauma and skeletal damage.]. Travma - Trauma, 16, 4, 7-10 [in Ukrainian].

4. Fil, A.Yu. (2014). Khirurhichna kontseptsiia likuvannia postrazhdalykh iz politravmoiu u hostromu periodi [Surgical concept of treatment of victims with polytrauma in the acute period]. Travma - Trauma, 15, 5, 20-23 [in Ukrainian].

5. Haida, I.M., Badiuk, M.I., \& Sushko, Yu.I. (2018). Osoblyvosti struktury ta perebihu suchasnoi boiovoi travmy u viiskovosluzhbovtsiv Zbroinykh Syl Ukrainy [Peculiarities of structure and current of modern combat trauma among servicemen of the Armed Forces of Ukraine]. Patolohiia - Pathology, 15, 1, 73-76 [in Ukrainian].

6. Prydruha, S.M. (2013). Pathogenetic features the late current manifestations in an experiment traumatic disease and its correction tiotryazolin. Journal of Health Sciences, 3, 111-120.

7. Hudyma, A.A., \& Pidhirnyi, V.V. (2007). Vplyv lansoprazolu, metronidazolu i klarytromitsynu na funktsionalnyi stan pechinky i yoho korektsiia tiotryazolinom v umovakh khronichnoho eksperymentalnoho hepatytu [Influence of lansoprazole, metronidazole and clarithromycin on the functional state of the liver and its correction with thiotriazolin in conditions of chronic experimental hepatitis]. Zaporizkyi medychnyi zhurnal - Zaporizhzhia Medical Journal, 5, 33-37 [in Ukrainian].

8. Stefanov, O.V. (Ed.). (2001). Doklinichni doslidzhennia likarskykh zasobiv: metodychni rekomendatsii [Preclinical drug studies: guidelines]. Kyiv: Avitsenna [in Ukrainian].

9. Hudyma, A.A., Mykhailiuk, I.A., \& Mykhailiuk, V.M. (2015). Dynamika pokaznykiv zhovchoutvoriuvalnoi funktsii pechinky u vidpovid na skeletnu, cherepnomozkovu ta poiednanu travmu $v$ rannii period travmatychnoi khvoroby [Dynamics of the indices of liver biligenetic function in reply to skeletal, cranial-cerebral and combined traumas in the early period of the traumatic disease]. Medychna i klinichna khimiia - Medical and Clinical Chemistry, 17, 3, 66-69 [in Ukrainian].

10. Volotovska, N.V., Cliff Nhokwara, T., \& Zhulkevych, I.V. (2019). Zminy aktyvnosti hlutationovoi systemy vnutrishnikh orhaniv u pershi hodyny eksperymentalnoho ishemichno-reperfuziinoho syndromu kintsivky, poiednanoho z krovovtratoiu ta mekhanichnoiu travmoiu
[Changes in the glutathione systems activity of internal organs in the first hours of experimental limb ischemiareperfusion syndrome, combined with blood loss and mechanical injury]. Zdobutky klinichnoi i eksperymentalnoi medytsyny - Achievements of Clinical and Experimental Medicine, (1), 23-27 [in Ukrainian]. Retrieved from: https:// doi.org/10.11603/1811-2471.2019.v0.i1.10043

11. Zachepa, O.A., \& Sushko, Yu.I. (2019). Porushennia antyoksydantno-prooksydantnoho balansu $v$ pechintsi za umov poiednanoi abdominalnoi i torakalnoi travmy [Violation of antioxidant-prooxidant balance in the liver under conditions of combined abdominal and thoracic trauma]. The All-Ukrainian Scientific and Practical Conference: Ekstrena medychna dopomoha vnadzvychainykh umovakh - Emergency Emergency Medical Services. (pp. 45-46). Ternopil: Ukrmedknyha [in Ukrainian].

12. Volotovska, N.V., \& Hudyma, A.A. (2011). Rol hemichnoi hipoksii v patohenezi porushen zhovchoutvoriuvalnoi i zhovchovydilnoi funktsii pechinky na tli skeletnoi travmy $v$ rannomu posttravmatychnomu periodi [The role of hemic hypoxia in the pathogenesis of disorders of the biliary and biliary functions of the liver and the background of skeletal trauma in the early posttraumatic period]. Zdobutky klinichnoi i eksperymentalnoi medytsyny - Achievements of Clinical and Experimental Medicine, 2 (15), 31-33 [in Ukrainian].

13. Chekman, I.S., Posokhova, Ye.A., \& Beregovaya, Ye.G. (1996). Mikrosomalnaya fermentnaya sistema organizma [Microsomal enzymatic system of the body]. Kyiv [in Russian].

14. Belenichev, I.F., Vizir, V.A., Mamchur, V.I., \& Kuryata, A.V. (2019). Mesto tiotriazolina $\vee$ galereye sovremennykh metabolitotropnykh lekarstvennykh sredstv [The place of thiotriazolin in the gallery of modern metabolitotropic drugs]. Zaporozhskiy meditsinskiy zhurnal - Zaporozhye Medical Journal, 21, 1, 118-128 [in Russian].

15. Dronov, O.I. Kovalska, I.O., Zemskov, S.V., Kozachuk, Ye.S., Bakunets, P.P., \& Zhulkevych, I.V. (2019). Otsinka bezpechnosti vnutrishnopechinkovoho vvedennia $10 \%$ rozchynu kaltsiiu khlorydu u shchuriv linii wistar: eksperymentalne doslidzhennia [Safety assessment of intrahepatic injection of $10 \%$ calcium chloride solution in wistar rats: experimental study]. Zdobutky klinichnoi i eksperymentalnoi medytsyny Achievements of Clinical and Experimental Medicine, 2, 125-129 [in Ukrainian]. 


\title{
НАРУШЕНИЕ БИОХИМИЧЕСКОГО СОСТАВА ЖЕЛЧИ В УСЛОВИЯХ СОЧЕТАННОЙ ТРАВМЫ ЖИВОТА И ГРУДНОЙ КЛЕТКИ В ПЕРИОД РАННИХ ПРОЯВЛЕНИЙ ТРАВМАТИЧЕСКОЙ БОЛЕЗНИ И ЕГО КОРРЕКЦИЯ ТИОТРИАЗОЛИНОМ
}

\begin{abstract}
Резюме
Вступление. Травмы продолжают оставаться самой распространенной причиной смертности во всем мире. В структуре боевой травмы тупые и проникающие повреждения грудной клетки и живота занимают третье место, уступая ранениям конечностей и головы.

Цель исследования - выяснить характер нарушения желчеобразовательной фрункции печени в условиях сочетанной травмы живота и грудной клетки крыс в ранний период травматической болезни и оценить эфрфективность его коррекции тиотриазолином.

Методы исследования. Эксперименты проведены на 86-ти нелинейных белых крысах-самцах массой 200-220 г, которых разделили на пять групп: контрольную и четыре исследовательских. Травмы наносили в условиях тиопентал-натриевого наркоза в дозе 40 мг/кг массы животного. В контрольную группу вошли интактные животные, которых только вводили в наркоз. В 1-й исследовательской группе крысам моделировали травму грудной клетки, во 2-й - тупую травму живота, в 3-й - эти травмы соче-

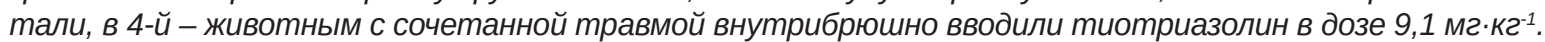
Через 1, 3 и 7 суток после нанесения травм в условиях тиопентал-натриевого наркоза у крыс катетеризировали общий желчный проток и в течение 60 мин собирали желчь, в которой определяли концентрацию суммарных желчных кислот и холестерола, рассчитывали холато-холестероловый коэфрфициент.

Результаты и обсуждение. При нанесении изолированных травм грудной клетки, живота и их сочетании существенно нарушалась желчеобразовательная фрункция печени, что проявлялось снижением синтеза холатов и возрастанием холато-холестеролового коэфициента. По тяжести развития печеночной диссрункции их можно распределить так: изолированная травма грудной клетки изолированная травма живота $\leftarrow$ сочетанная травма. Вследствие выявленных нарушений существенно повышался холато-холестероловый коэффрициент, который доминировал в условиях изолированной травмы живота и сочетанной травмы. Смещение баланса в сторону накопления холестерола усиливало литогенные свойства желчи. Семидневное применение тиотриазолина в группе животных с сочетанной травмой способствовало существенному увеличению содержания в желчи суммарных желчных кислот, возрастанию холато-холестеролового коэфрфициента, не влияло на концентрацию холестерола в желчи.

Выводы. Сочетанная травма живота и грудной клетки способствует большему снижению фрункциональной способности печени по сравнению с изолированными повреждениями. В его основе лежит угнетение синтетических процессов в микросомальной системе гепатоцитов. Тиотриазолин способен снизить негативное воздействие патогенных фракторов травмы на функциональную способность гепатоцитов, что следует учитывать в комплексной интенсивной терапии сочетанной травмы живота и грудной клетки.
\end{abstract}

КЛЮЧЕВЫЕ СЛОВА: сочетанная травма; грудная клетка; живот; желчеобразование; тиотриазолин.

O. A. Zachepa, A. A. Hudyma, Yu. I. Sushko, T. Ya. Yaroshenko I. HORBACHEVSKY TERNOPIL NATIONAL MEDICAL UNIVERSITY

\section{DISTURBANCES OF THE BIOCHEMICAL COMPOSITION OF BILE IN CONDITIONS OF COMBINED ABDOMINAL AND BREAST TRAUMA IN PERIOD OF EARLY MANIFESTATIONS OF TRAUMATIC DISEASE AND ITS CORRECTION WITH THIOTRIAZOLINE}

\section{Summary}

Introduction. Injuries continue to be the most common cause of death worldwide. In the structure of combat trauma, blunt and penetrating injuries to the chest and abdomen occupy the third place, second to the injuries to the extremities and the head. 
The aim of the study - to find out character of disturbance of bile-forming function of a liver under the conditions of the combined injury of abdomen and a chest of rats in the early period of traumatic illness and to evaluate the effectiveness of its correction with thiotriazoline.

Research Methods. The experiments were performed on 86 non-linear white male rats weighing 200-220 g, which were divided into five groups: control and four experimental. Injuries were inflicted under thiopental sodium anesthesia at a dose of $40 \mathrm{mg} / \mathrm{kg}$ animal weight. The control group included intact animals that were only anesthetized. In experimental group 1 rats were simulated chest injury, in group 2 - blunt abdominal injury, 3 - combined injuries, 4 - animals with combined trauma were injected intraperitoneally with tiotriazoline at a dose of $9.1 \mathrm{mg} \cdot \mathrm{kg}^{-1}$. After 1 , 3 and 7 days after the injury under the conditions of thiopental sodium anesthesia, rats were catheterized into the common bile duct and bile was collected for $60 \mathrm{~min}$, in which the concentration of total bile acids and cholesterol was determined, and the cholate-cholesterol ratio was calculated.

Results and Discussion. In the application of isolated injuries of the chest, abdomen and their combination, the bile-forming function of the liver was significantly impaired, which was manifested by a decrease in the synthesis of cholates and an increase in the cholate-cholesterol ratio. The severity of liver dysfunction can be divided as follows: isolated chest injury $\leftarrow$ isolated abdominal injury $\leftarrow$ combined injury. As a result of the violations found, the cholatecholesterol ratio increased significantly, which was dominated by isolated abdominal trauma and combined trauma. Shifting the balance toward cholesterol accumulation increased the lithogenic properties of bile. The seven-day administration of thiotriazoline in the group of animals with combined trauma significantly increased the total bile acid content in the bile, increased the cholate-cholesterol ratio, did not affect the cholesterol concentration in the bile.

Conclusions. Combined abdominal and thoracic trauma contributes to a greater reduction in liver functional capacity compared to isolated lesions. It is based on the inhibition of synthetic processes in the microsomal system of hepatocytes. Thiotriazoline is able to reduce the negative impact of pathogenic factors of trauma on the functional capacity of hepatocytes, which should be taken into account in the intensive care of combined abdominal and breast trauma.

KEY WORDS: combined trauma; breast; abdomen; bile formation; thiotriazoline.

Отримано 15.10 .19

Адреса для листування: А. А. Гудима, Тернопільський національний медичний університет імені І. Я. Горбачевського МОЗ України, майдан Волі, 1, Тернопіль, 46001, Україна, e-mail: gudyma@tdmu.edu.ua. 